Prethodno priopćenje UDK 111(091)Parmenid, Platon doi: $\underline{10.21464 / \text { fi36104 }}$ Primljeno 1. 12. 2015 .

\author{
Nikola Tatalović \\ Univerzitet u Novom Sadu, Filozofski fakultet, Dr Zorana Đinđića 2, RS-21000 Novi Sad \\ nikolatata@gmail.com
}

\title{
Platon i Parmenid: bludnja i bespuće
}

\begin{abstract}
Sažetak
Autor u radu analizira odnos Platonove pozne misli bitka spram elejskog nasljeđa koje stoji u samom osnovu postavke o ideji iz srednjeg perioda. Analiza pokazuje da Parmenidova poema O prirodi predstavlja problemski okvir Platonove misli, odnosno da se zadatak utemeljenja misli o ideji, kao onoga što je u srednjem periodu prosto postulirano, mora kritički obračunati s Parmenidovom mišlju bitka. Platonove ideje pokazuju se kao umnožen Parmenidov bitak, ali su kao takve već uvijek istina mnoštva. Stoga, utemeljenje postavke o ideji zahtijeva kritiku Parmenidovog načina mišljenja bitka, kritiku koja otvara prostor za nov način mišljenja ideje kao bića po sebi. Patricid je Platonova odluka za bespuće, bludnja koja vodi putu onih koji lutanju dvoglavi.
\end{abstract}

\section{Ključne riječi}

Platon, Parmenid, ideja, bitak, nebitak, jedno, mnoga, istina, mnijenje, bespuće

Platonovi pozni dijalozi svjedočanstvo su svojevrsnog raskršća na kojem se njegovo mišljenje nalazilo, svjedočanstvo ukrštanja dvaju putova koji vezuju Gordijev čvor Platonovog mišljenja: puta otvorenog sofističkim pokretom kao onim koji određuje Platonovu situaciju mišljenja i puta neposrednog govorenja bitka koji karakterizira predsokratsku misao. Unutar Platonovih ranih i zrelih dijaloga, Sokratov lik simbol je borbe za istinu na tom novootvorenom području, simbol programa mišljenja određenog u Fedonu kao bijeg u logos.

Ako je lik Sokrata i simbol tog nastojanja, on ne čini transparentnim samo to područje. Sokratov zahtjev za jedinstvom mnoštva na području moralnosti, zahtjev za definicijom, utro je put Platonovoj postavci o ideji. Međutim, postuliranje ideje je zapravo samo postavka osnovnog problema, ne i njegova eksplikacija ili eventualno rješenje. Zadatak ekspliciranja postulata ideje, kojeg pozni Platon poduzima, podrazumijeva sučeljavanje s prešućenim pretpostavkama vlastitog mišljenja, sučeljavanje koje nadilazi Sokratovo trebanje općeg i vodi osvjetljavanju prostora ukrštanja dvaju, naizgled, najudaljenija puta, kao mjestu koje omogućava sâmo Platonovo mišljenje. Simbol te raskrsnice, centralna figura koju zatičemo na tom raskršću je Parmenid, o čemu najbolje svjedoči Platonov istoimeni dijalog, dijalog na koji se Platon referira u Sofistu i Teetetu.

Dijalog Parmenid može se razumjeti kao poduhvaćanje zadatka izlaganja naznake programa zacrtanog u Fedonu. U njemu Platon nastoji utemeljiti vlastitu postavku o ideji koju je u ranijim dijalozima samo postulirao. Dijalog Parmenid predstavlja otvaranje za nov način mišljenja bitka koje nastoji prepoloviti između sofističke Scile i elejske Haribde. 
U Parmenidu, prije svega »gimnastičkim« dijelom dijaloga, Platon pokazuje nužnost mišljenja jednog i mnogih, istog i razlike, itd. - nužnost su-učešća ideja, odnosno pokazuje sućinsku pripadnost elejaca (filozofa) i sofista. $\mathrm{Na}$ taj način on izgrađuje pojmovnu aparaturu kako za kritiku sofista (Protagore u Teetetu), kritiku koju će Aristotel naprosto preuzeti, držeći je definitivnom, ${ }^{1}$ tako i za kritiku Parmenida, te otvara prostor za učenje o najvišim rodovima kao izlaganju samog logosa u Sofistu. Kritika sofista i kritika elejaca se, po Platonu, mora izvoditi paralelno iz razloga što obje strane dijele istu logiku - logiku onoga ili-ili. Sofisti preokreću smisao Parmenidovog puta bitka, ali tim preokretanjem potvrđuju da je logika toga puta i dalje mjerodavna za njihovo mišljenje. Međutim, kritika Parmenida (a onda i sofista) nije nešto što se preuzima iz izvanjskih razloga. Suočavanje s Parmenidovom mišlju, koje je u Sofistu označeno kao patricid, ${ }^{2}$ svjedočanstvo je elejskog nasljeđa Platonovog učenja o bitku.

Takozvana teorija ideja postulira ideje kao neku vrstu »umnoženog« Parmenidovog bitka. Međutim, za razliku od Parmenidovog učenja, ideje su (kao ono jedno, uvijek sebi jednako i nepropadljivo) uvijek već istina mnoštva, onoga propadljivog i nikada sebi jednakog. To znači da je mišljenje odnosa jednog i mnogih sâmo središte Platonovog učenja o ideji. Platon u Filebu izuzetno transparentno ukazuje na temeljno pitanje vlastitog mišljenja:

»Tvrdimo da se jedno i mnoštvo, što se utvrđuje u raspravljanju, pojavljuje kao isto u svemu o čemu se govori, i to svagdje i uvijek, već davno i sada. I to nikada neće prestati niti je istom sada započelo, nego je takvo nešto, kako se meni čini, besmrtna i bestarosna pojava samih naših međusobnih govora. $\ll^{3}$

Stoga, možemo zaključiti da je svako drugo pitanje za Platona moguće tek na temelju odlučenosti u pogledu na ovo prvo i osnovno pitanje.

Dakle, horizma nije nešto što Platon naprosto postulira, bez obzira na to u kolikoj mjeri on uspijeva riješiti temeljni problem vlastitog mišljenja. Naprotiv, horizmu Platon, moglo bi se reći, nasljeđuje. Horizma je postavljena nastojanjem Parmenida da misli čisto, da misli bitak kao bitak, nastojanjem koje vodi jazu istine bitka i smrtničkog mnijenja. Međutim, u onoj mjeri u kojoj Platon ideje postulira po uzoru na Parmenidovu misao bitka, njegova misao stoji pod znakom putova mišljenja naznačenim u poemi $O$ prirodi. Riječju, Platonovo suočavanje s Parmenidovom mišlju ujedno je suočavanje s vlastitim postulatom ideje koji je, imajući u vidu prije svega Fedona, Gozbu i Državu, sve vrijeme zakrivao vlastitu aporetičnost prikrivajući vlastito porijeklo.

Moglo bi se reći da su osnovni problemi Platonove filozofije postavljeni u Parmenidovoj poemi, ali i više od toga: Platon je prvi filozof koji je svjestan toga koliko svaka misao duguje misli elejaca, kao i toga da se mišljenje mora kritički suočiti s elejskim nasljeđem. Ukoliko Parmenidovu poemu razumijemo kao osnovni problemski okvir Platonove filozofije, utoliko se, polazeći od nje, možemo otvoriti za smisao Platonovog od-govora.

\section{I.}

Način pitanja svojstven Parmenidovoj misli, kao i artikulacija onoga tim pitanjem pitanog, predstavlja događaj unutar predsokratovske filozofije, ali i filozofije uopće. Poetska forma nimalo ne umanjuje čistinu pitanja o bitku, čistinu kojom se Parmenidova misao razlikuje od čitave predsokratovske filozofije. Da se elejska misao izdvaja unutar cjeline predsokratovske misli primjećuje i Aristotel kada govori o karakteru osnovnih pitanja koja zaokupljaju tu misao: 
»Što se tiče istraživanja toga je li bitak jedno i nepokretno [...] to ne pripada istraživanju prirode [...] već to pripada ili nekoj drugoj nauci, ili onoj koja je zajednička za sva /načela/.«4

Moguće je da Aristotel ovdje misli na karakter pitanja svojstven prvoj filozofiji, ali je jednako moguće da misli i na dijalektiku. Također, Aristotel elejskom učenju odriče arheološki karakter, ono što je tipično za fizičare, zato što jedno koje je jedno i sve ne može biti načelo jer načelo je načelo nečega, nekog mnoštva. ${ }^{5}$ Za samog Platona, Parmenid stoji nasuprot sve ostale predsokratovske misli tezom o nepokretnosti (Theaet. 152e) jednog-sve-bića (Soph. 242d, Parm. 128b1).

Parmenideova poema $O$ prirodi postavlja čitav niz pitanja: kako uskladiti put

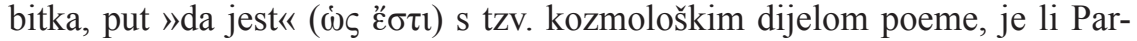
menidova misao ujedno i kritika drugih filozofa i kojih to (Milećana, pitagorejaca, Heraklita), ${ }^{6}$ jesu li mnijenja smrtnika čisti privid, jesu li ona nekako i u kojem smislu, je li upravo kozmološki dio poeme pokušaj da se taj svijet mnijenja smrtnika razumije i u kojoj se mjeri to postiže, što je subjekt onog

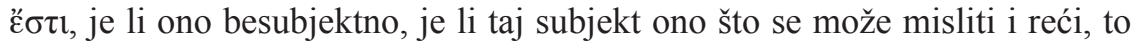
jest, je li subjekt bitak ( $\tau$ ò ö $v$ ). Interes našeg rada ne može biti odgovaranje na sva ta pitanja, već se ograničavamo na analizu Parmenidove misli bitka i napetosti koje ona sa sobom nosi kao osnovu Platonove misli.

Uvodni dio poeme govori o mladiću koji, napuštajući putove smrtnika, pravdom i pravednošću dospijeva pred boginju koja mu se obraća sljedećim riječima:

»Potrebno je sve da spoznaš -

Lijepo zaokružene Istine sigurno srce,

A i dokaza istine lišena smrtnika mnijenja.

Ipak, naučit ćeš i to kako je mišljenja takva

nužno ispitati brižljivo posve kroz sve u svemu. « ${ }^{7}$

Ovo je svojevrsni uvod, najava onoga o čemu će boginja govoriti. Već ovim se otvara možda i najteži problem u tumačenju poeme, a to je zašto je pored spoznaje istine neophodno spoznati i ono što je »dokaza istine lišeno«? Ovo mjesto predmet je spora najrazličitijih interpretacija, ali i ključan moment za razumijevanje Platonove misli i odnosa iste spram Parmenida, te je naš pristup istom mjestu vođen prije svega ovim posljednjim. ${ }^{8}$ Tome ćemo se sva-

Kritika Protagore unutar opovrgavajućeg dokaza načela neproturječnosti u knjizi $\Gamma$ i K Aristotelove Metafizike.

2

Platon, Sofist, u: Platon, Kratil, Teetet, Sofist, Državnik, Plato, Beograd 2000., str. 241 i d.

3

Platon, Fileb, u: Platon, Dijalozi Teetet i Fi$l e b$, Naprijed, Zagreb 1979., str. 119, 15 i d.

4

Aristotel, Fizika, Paideia, Beograd 2006., str. $9,185 \mathrm{a} 3-5$.

5

Isto.

6

Usp. Francis M. Cornford, Plato and Parmenides. Parmenides' Way of Truth and Plato's
Parmenides, Bobbs-Merrill, Indianapolis, New York 1939

7

Hermann Diels, Predsokratovci: Fragmenti I, Naprijed, Zagreb 1983., str. 207, DK B1.28-32.

8

Interes našeg rada je ograničen na razumijevanje Platonovog odnosa spram Parmenida te tom pitanju prilazimo iz Platonove situacije mišljenja. O pristupu pitanju odnosa puta »da jest« i kozmološkog dijela Parmenidove poeme, koji se drži samog Parmenida, usp. Gwilym E. L. Owen, »Eleatic Questions«, u: Gwilym E. L. Owen, Martha Craven Nussbaum (ur.), Logic, Science, and Dialectic: Collected Papers in Greek Philosophy, Cornell University Press, Ithaca, New York 1986., str. 3-26. 
kako vratiti. Prethodno je neophodno, unutar same poeme, pokušati razumjeti smisao ove tvrdnje.

U drugom fragmentu boginja izlaže jedine zamislive putove istraživanja, putove koji su namijenjeni (čistom) mišljenju, misli koja ne luta: prvi, »prema jednom bitak jest, a nebitka nema - staza je (to) Uvjerenja (koja) Istinu slijedi«, ${ }^{9} i$ »prema drugom nebitak jest i nužno postoji - to je, kažem ti, sasvim nespoznatljiva staza: Ne možeš spoznati ono što nije (jer moguće nije) niti izreći $\ll,{ }^{10}$ da bi konačno u trećem fragmentu rekla »jer isto je misliti kao i biti ${ }^{11}$ Ovim je određena bitna supripadnost mišljenja/govorenja i bitka. Ta upućenost svakog mišljenja/govorenja na ono što jest nije tu da bi »postavila« bitak, već da bi potvrdila ontološki primat bitka. Iz samog bitka proizlaze njegove »karakteristike«. Iz njega samog i način na koji ono jest - nužnost. Iz bitka samog proizlaze i osnovni principi bitka, a time i principi mišljenja i govorenja. To nisu načini na koje se »dokazuje«, odnosno izvodi nužnost bitka, već se iz nužnosti bitka izvodi nužnost mišljenja bitka: prvi, »postoji bitak « ${ }^{12}$ ili »biti jest« - princip identiteta; drugi, »nikada neće nadvladati to da nebitak jest $\ll,{ }^{13} »$ niti misliti, naime, niti reći ne smiješ da nebitak jeste $\ll^{14}$ - princip neproturječnosti; treći, »tako je nužno sasvim da jest ili da nije «, ${ }^{15}$ »a odluka je o tome ova: jest ili nije « ${ }^{16}$ - princip isključenja trećeg.

Na temelju principa bitka, naime njegove nužnosti, pokazuje se nemogućnost drugoga puta, odnosno puta da nije i kako mora ne biti. Tako preostaje samo prvi put, put »da jest i kako ne može ne biti«. Na tom putu ispostavlja se čitav niz odredaba onoga što jest: cijelo, sada-čitavo, cijelo-puno, jedno, jednako sebi, isto u istom, po sebi, sa svih strana konačno (sfera) - ima granicu (savršenstvo). Međutim, Parmenid čitavim nizom negativnih određenja bitka, koja prevladavaju nad pozitivnim, na mala vrata uvodi sam nebitak, to jest govor o onom drugom, onom naspram, o mnoštvu koje se sa stanovišta bitka određuje kao ništa. Upravo ovaj moment ukazuje na ono što će biti predmet Platonove kritike Parmenida: da svaki govor o bitku podrazumijeva govor o nebitku. Međutim, kako je Parmenidova misao o bitku određena onim ili-ili, tako sve ono drugo, koje samim govorom o bitku biva uvučeno u bitak, jest označeno kao ništa. Odatle samo bitak jest i ono jedino što može biti mišljeno i govoreno. ${ }^{17}$

Parmenidov bitak je jedno-sve-biće. Ono nije cjelina mnoštva pojedinačnih bića, već je samo jedno biće. U pogledu na prethodno, za Parmenidovo tò öv Slobodan Žunjić kaže sljedeće:

»... ta riječ, u stvari, označava nešto manje od bivstvovanja (Sein), ali svakako nešto više od bivstvujućeg (das Seiende). ${ }^{18}$

To da bitak jest nije puka tautologija, ne ponavlja se ono već rečeno, već i govori nešto više:

»U prvom sloju njemu 'pripada' ono što 'slijedi' iz njega samog, a u drugom sloju sugerira da njemu (a ne nečemu drugom) pripada karakter 'jestanja' ili postojanja. To kao da je dovoljno za zaključak da bitak kao subjekt nije identičan sa svojim predikatom, naime, da bitak nije isto što i postojanje. $\ll^{19}$

Ukoliko je Parmenidov bitak jedno-sve-biće, te time ono jedino što može biti mišljeno i rečeno, utoliko se izlaganjem bitka izlaže sve što se može reći i misliti. Međutim, time što je izložen put »da jest i kako ne može ne biti« poema se ne završava, već se završava »o istini pouzdan govor i misao «. ${ }^{20}$ Time se govor boginje vraća na početak poeme, u kojem je naznačeno da je neophodno spoznati sve, kako »lijepo zaokružene Istine sigurno srce«, tako i 
»dokaza istine lišena smrtnika mnijenja«. Postavlja se pitanje zašto je neophodno spoznati i drugi put, put mnijenja smrtnika, ako u njemu nema istinskog pouzdanja. Ukoliko se pod smrtničkim mnijenjima razumije drugi put od dva naznačena u drugom fragmentu (DK B2.5), utoliko bi to značilo da Parmenid proturječi samom sebi - nikakav nužan, smislen govor ni misao o njemu nisu mogući.

Put mnijenja smrtnika može biti samo treći put, koji se uvodi u šestom fragmentu, put onih koji lutaju dvoglavi: »koji smatraju da su bitak i nebitak isto (ali) i neisto ${ }^{21}$ Taj put očigledno nije put »da nije i da je nužno da nije«, koji je na samom početku odbačen i o kome boginja govori kao o potpuno neprohodnom. On je uvijek već isključen kao mogući put istraživanja samim prvim putom i na više mjesta boginja zabranjuje mladiću da ide tim putom. Doduše ona ga odvraća i s puta mnijenja, ali, čini se, iz sasvim drugih razloga. Radi se o dvije potpuno različite epistemičke razine, o mišljenju i mnijenju. U sedmom fragmentu boginja odvraća mladića od smrtničkog načina spoznaje i govori mu da, bez oslonca na oči, uši i jezik, spoznaje i drži se pravog puta - puta mišljenja: »nego prosudi mišlju«.22

Putovi istraživanja u drugom fragmentu putovi su čistog mišljenja, putovi mišljenja koje ne luta jer je vođeno »principima« bitka. Put koji se uvodi kasnije je put mišljenja koje luta, dakle, mišljenja koje je lišeno nužnosti. Na taj način uspostavljaju se dva puta: put čistog mišljenja i put mišljenja koje luta, oslonjeno na čula. Time se uspostavlja horizma. Nije moguće na temelju osnovnih postavki o bitku izvesti svijet onog nestalnog, promjenljivog, onog na čemu se zasniva mnijenje smrtnika jer na temelju prvog puta »da jest i da ne može ne biti« nije moguć pouzdan govor o onome što nema one karakteristike koje važe za bitak, ali to ne znači da nikakav govor nije moguć o onome nasuprot bitka. Međutim, taj govor je u strogom smislu prazan govor:

H. Diels, Predsokratovci: Fragmenti I, str. 208, DK B2.3-4.

10

Isto, DK B2.5-8. Govoreći o mišljenju kod Parmenida kao o svjedočanstvu bitka, o mišljenju kao onome što je iskazano $u$ bitku, Gadamer kaže sljedeće: »Oznakama bitka koje Parmenida vode putem istine pripada i noein. Jasno je što to znači; bitak je apsolutna prisutnost i to upravo znači 'prisutnost za...'. Istina je otkrivenost te prisutnosti. Stoga je s bićem uvijek zajedno prisutno ono čemu je biće prisutno - 'mišljenje'. Potrebno je da, koristeći pojmove svog jezika, ne zapadnemo u neku 'idealističku' interpretaciju antičkog mišljenja. Jer to što je mišljenje mišljenje nečeg mislećeg još uvijek ne znači da je biće mislećeg ono odakle se razumiju mišljenje i u njemu zamišljeno biće... Pa ipak je bez sumnje točnije reći: biti mišljen i biti su isto, nego: mišljenje i biće su isto." (Hans-Georg Gadamer, »O predistoriji metafizike«, Theoria, 40 (4), 1997., str. 93-108, 104-105).

11

Isto, H. Diels, Predsokratovci: Fragmenti I, DK B3.
13

Isto, str. 211, DK B7.1.

14

Isto, DK B8.8-9

15

Isto, DK B8.11.

16

Isto, DK B8.15-16.

17

G. E. L. Owen, »Eleatic Questions«, str. 6.

18

Slobodan Žunjić, Fragmenti elejaca, BIGZ, Beograd 1984., str. 15.

19

Isto, str. 8-9.

20

H. Diels, Predsokratovci: Fragmenti I, str. 212, DK B8.50.

21

Isto, str. 209, DK B6.8-9.

22

Isto, str. 211, DK B7.5.

12

Isto, str. 209, DK B6.1. 
»... sve što su ljudi nazvali, s vjerom da istinu vide tek pusto je ime: nastanak kao i propast, nebitak (kao) i bitak. $\ll^{23}$

Taj govor ne govori ništa.

O smislu izlaganja smrtničkih mnijenja, »poretka lažnog«, ${ }^{24}$ možda govori fragment osmi, gdje boginja kaže:

»... poredak iznosim taj ti što suvislim čini se posve, zato da nikada ne daš zavesti se smrtnika stavom. $\ll^{25}$

Međutim, drugi dio poeme je neusporedivo duži od prvog, što postavlja pitanje zašto je Parmenid najveći njen dio posvetio upravo lažnom poretku. Kako izlaganje onog što nije istina, što je unaprijed određeno kao suprotnost pravom i jedinom putu, što pravi put samim sobom isključuje, može pomoći shvaćanju istine ili odvratiti od neistine, to kozmološki dio poeme ne pokazuje uzet sam po sebi. U čemu je smisao takozvanog kozmološkog dijela poeme? Izlaganje onoga što se, strogo govoreći, ne može izložiti. Ponovo se vraćamo na početak:

»Ipak, naučit ćeš i to kako je mišljenja takva nužno ispitati brižljivo posve kroz sve u svemu.«

Prethodno rečeno ukazuje na to da ispitivanje smrtničkih mnijenja nije nešto usputno, nego je s jednakom nužnošću zadatak mišljenja. Owen svrhu kozmološkog dijela poeme određuje kao u potpunosti dijalektičku, kao onu koja daje najvjerojatnije izlaganje pretpostavki od kojih polaze mnijenja smrtnika. ${ }^{26}$ Slično mišljenje iznosi i Žunjić:

»... u mnijenjima smrtnika nema istinskog pouzdanja, ali mnijenja nisu sasvim neosnovana. Iako završavaju u prividu, u trećem dijelu poeme dokazuje se da slijede iz pretpostavki koje se prihvaćaju [...] ali njihova valjanost je problematična jer je problematična valjanost polaznih pretpostavki. $\ll^{27}$

Ukoliko stvari zaista tako stoje, utoliko time nije odgovoreno na pitanje nužnosti ispitivanja mnijenja smrtnika. To ostaje skriveno. Ako je svijet pojavnog ništavan sa stanovišta bitka, to ne znači da on nekako nije. Međutim, to se na osnovu Parmenidove misli o bitku, njegovih »principa« i načina na koji ono jest, ne da konzekventno izvesti te je time moguće govoriti samo o istinskom i neistinskom »svijetu«, koji jedan drugog isključuju i koji su potpuno odvojeni. Ako bi pojave i »morale biti valjane«, to se na temelju Parmenidovog mišljenja bitka ne može vidjeti, kao što se ne može vidjeti ni zašto je neophodno ispitati ih »nužno posve kroz sve u svemu«. Istina bitka neistina je svega drugog - horizma je postavljena.

\section{II.}

Ako su ideje bitka onog propadljivog, mnogog, to znači da su ideje izraz Platonove osnovne misli, misli jednog i mnoštva. Ideje se na taj način pokazuju kao jedinstvo mnoštva. Osnovne odlike ideja su: da su po sebi, da je svaka od njih jedna, da su potpuno ostvarenje onoga što jest, savršenstvo, samopredikacija ili jedinstvo esencije i egzistencije. Nasuprot idejama stoje stvari koje prisutnošću ideja ili učestvovanjem u idejama bivaju ono što »jesu«. To dovodi do pitanja načina na koji se ostvaruje ta veza. Ovo pitanje, ovaj problem, nešto je čega je, čini se, Platon još od Fedona bio svjestan. U Fedonu, Sokrat je nesiguran u pogledu karaktera odnosa ideja-stvar, je li taj odnos prisutnost

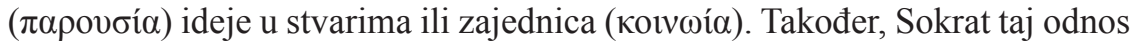
opisuje i kao nastojanje, uvoljuje ( $\beta$ ov $\lambda \varepsilon \tau \alpha \imath)$ stvari da oponašaju ideju i kao 
učestvovanje ( $\mu \varepsilon \dot{\varepsilon} \theta \varepsilon \xi 1 \varsigma)$ stvari u ideji. Mi ćemo se u pokušaju razumijevanja problema odnosa ideja i stvari poslužiti uvodnim dijelom Parmenida. Razlog za to je taj što je tu takozvana teorija ideja izložena u svim aspektima koji su i u ranijim dijalozima bili naznačeni, ali i u jednom novom vidu (ideja kao misao). Također, nigdje se kao u predigri Parmenida Platon ne hvata direktno u koštac s problemom odnosa ideja-stvar.

Sam dijalog predstavlja jedan od najtežih, ako ne i najteži Platonov tekst za razumijevanje. Dijalog je više nego zagonetan. To se odnosi kako na uvod, tako i na samu dijalektičku igru, kroz njenih osam (ili devet) prohoda dvije hipoteze. Osnovni problem koji se u uvodnom dijelu razmatra je postavka ideje kao jedinstva mnogih. Okvir ovoga razmatranja čini trijada Sokrat-Zenon-Parmenid. U literaturi se često postavlja pitanje uloge »mladog « Sokrata, nevještog u dijalektici, te pitanje progovara li ovdje Platon kroz usta Parmenida, obrušavajući se na učenje o idejama iz srednjeg perioda, nastojeći da pokaže da je ono neutemeljeno, da bi potom pokazao i neutemeljenost Parmenidove misli o jednom-sve-biću. Jesu li argumenti koji se iznose protiv teorije ideja zaista tako ubitačni, ruše li oni teoriju ideja i ako je tako, kako objasniti Platonovo ostajanje pri teoriji ideja u zaključku uvodnog dijela, te u kasnijim dijalozima. ${ }^{28}$ Naše je mišljenje da ta tri lika čine nerazdvojno jedinstvo Platonovog promišljanja ideje, odnosno odnosa ideja-stvar. Oni čine temelj Platonovog koncepta ideje, oni stoje u samom osnovu Platonove misli - zato su i pozvani.

Upravo je Sokrat svojim upornim nastojanjem na zahvaćanju mnoštva onim jednim - definicijom - u etičkom području utro put Platonovoj misli ideje. Sokratov uvid u ono opće predstavlja za Platona postavku osnovnog problema. Sagledavanje općosti u etičkom predstavlja temelj na kojem Platon gradi vlastitu misao, misao ideje, a onda i misao jednog, kojom se udaljava od Sokrata, odnosno tu se postavljaju problemi koji Sokratovu misao nadilaze. Zatim, tu je Parmenid, čiji napor mišljenja bitka Platon sažima u stav »sve je jedno« (Soph. 242d, Parm. 128b1). Također, Parmenid za Platona stoji, čini se, nasuprot cjelokupne predsokratske misli s tvrdnjom o nepokretnosti (jednog) bića (Theaet. 152e). Platonove ideje su na izvjestan način »umnožen « Parmenidov bitak, odnosno one nose sve one bitne momente koje je Parmenid pripisivao bitku, s tom razlikom što su ideje za Platona uvijek već istina mnoštva. Treća figura je Zenon, poznat po svojim aporijama, odnosno nastojanju da pokaže nemogućnost mnoštva na njemu samom. Zenonovi paradoksi, kao što i sama riječ kaže, usmjereni su protiv uobičajenih predstava da mnoštvo postoji. U toj usmjerenosti protiv uobičajenih shvaćanja Zenon razvija metodu koja će kasnije biti nazvana dijalektikom. Platon će i u Parmenidu i u Sofistu naznačiti da ta metoda svoje izvorište ima u elejskoj misli.

Predigra počinje Sokratovim rezimiranjem Zenonovih aporija i tumačenjem njihova smisla. Sokrat traži da se ponovi prva pretpostavka prvog dokaza.

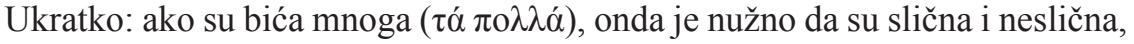

23

Isto, str. 212, DK B8.38-39.

24

Isto, DK B8.52.

25

Isto, str. 213, DK B8.60-61.

26

G. E. L. Owen, »Eleatic Questions«, str. 9.
27

S. Žunjić, Fragmenti elejaca, str. 74.

28

Usp. Paul E. More, »The Parmenides of Plato«, u: Philosophical Review, god. 25, sv. 2., 1916., str. 121-142. doi: http://dx.doi. org/10.2307/2178705. 
što je nemoguće. Ako ih snalazi ono što je nemoguće, onda je nemoguće da ih bude mnogo, odnosno ne postoji mnogo (bića). ${ }^{29}$ Sokrat ističe bitnu pripadnost Zenonove misli Parmenidovoj, čak kaže da je Zenon mislio »baš isto«, »no, preokrećući (stvar) kuša nas zavesti kao da govori nešto drugo «. ${ }^{30}$ Kao i u Sofistu, Platon kroz Sokrata ovdje određuje Parmenidovu misao stavom »sve je jedno «. ${ }^{31}$ Zenon, negirajući postojanje mnogih, tako govori gotovo isto što i Parmenid. ${ }^{32}$

Reagirajući na Sokratovu tezu da se u tom spisu radi o nečemu uzvišenom, iznad snage nas ostalih, Zenon kaže da Sokrat istinu tog spisa nije u potpunosti shvatio. ${ }^{33}$ Zenon tvrdi nekoliko stvari: prvo, da spis nije uzvišen, kako to Sokrat misli, da ne razrađuje nešto veliko; drugo, spis je pomoć Parmenidovoj tezi; treće, spis je napisan protiv onih koji tu tezu ismijavaju; ${ }^{34}$ četvrto,

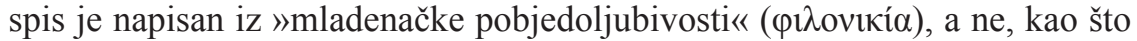
Sokrat pretpostavlja, iz staračkog »častoljublja« ( proizlazi da Platon drži Zenona za antilogičara. Naime, za Platona dijalektika nije vještina protivljenja (antilogika). Dijalektika se kreće suprotnostima, ona nije tu da bi proturječila, odnosno pobijala. Ako nosi u sebi i moment antilogičkog, onda je to iz razloga da bi pridobila sugovornika za samu stvar (pedagoški moment dijalektike). Platon o razlici antilogike i dijalektike u $\mathrm{Dr}$ žavi kaže slijedeće:

»Kako je sjajna moć vještine proturječenja [...] mnogi i nehotice u nju upadaju vjerujući da se ne prepiru, nego da se bave dijalektikom, a u stvari oni ne mogu ono što je rečeno razložiti po vrstama i ispitivati nego progone i hvataju sugovornika u proturječnosti samo po praznoj riječi, te se svađaju umjesto da jedan drugom govore što treba. «35

Pored antilogičkog karaktera Zenonove misli, Platon ističe još jedan moment, koji je u izvjesnom smislu određen negativno, a to je pobjedoljubivost. U Državi (581c i dalje) Platon razlikuje tri soja ljudi: ljubitelje mudrosti, ljubitelje pobjede i ljubitelje dobiti. Odričući oruđe prosuđivanja (logos) ljubiteljima pobjede i dobiti, Platon zaključuje da ono može pripadati samo ljubitelju mudrosti. Tako je Zenon dvostruko »diskvalificiran « ${ }^{36}$ Ovo, međutim, ne moraju biti jedini razlozi Zenonovog napuštanja rasprave. Moguće je da, s obzirom na to da govori isto kao Parmenid, ulaskom Parmenida u dijalog Zenon biva suvišan. Mada, ako i Sokrat napušta razgovor u drugom dijelu dijaloga, to može značiti i nešto više.

Platon, puštajući Zenona da unaprijed sebe »diskvalificira«, daje riječ Sokratu i u izvjesnom smislu nastoji pobiti Zenonov prvi dokaz. Sokrat napada drugu premisu Zenonovog argumenta, koja tvrdi da ništa ne može biti slično i neslično. Sokrat uvodi ideju sličnosti i njoj suprotnu ideju nesličnosti, a druga bića, koja se nazivaju mnogima, sudjeluju i zahvaćaju u te dvije ideje. Učestvovanjem, odnosno uzimanjem učešća slična su slična u mjeri u kojoj uzimaju učešća u sličnosti i obrnuto, a ona koja zahvaćaju u obje ideje su slična i neslična. Sokrat ne vidi nikakav problem u tome da stvari jesu mnoštvene zahvaćanjem u mnoštvo ideja i uzimanjem učešća u jednom. To, izgleda, nije pravi problem. Pravi problem i predmet pravog čuđenja bio bi »da su sama ona slična (postala) neslična ili ona neslična slična «, ${ }^{37}$ zato što se stvari mogu pokazati u različitim vidovima, obzorima, ali da se sam vid pokaže u različitim obzorima to bi bio pravi problem - da se ideje mogu u samima sebi miješati i razdvajati među sobom.

Aporije mnoštva tako se, prema Platonu, ne pokazuju kao aporije jer je ono čulno »po sebi« mnoštveno i promjenljivo, što ne znači da ono nije. Međutim, ideje jesu ono jedno koje omogućava to mnoštvo u njegovoj mnoštvenosti. Drugim riječima, da se neka pojedinačnost može pojaviti kao nešto jedno, a i 
u različitim aspektima (kao mnoštvo), pravi predmet divljenja bio bi, zaključuje Sokrat,

»... ako bi netko mogao istu tu besputnost (pokazati) svakojako isprepletenu u samim idejama (naime, ako bi netko mogao) kako baš razložiste za vidljiva bića, pokazati tako i u tima razumom dohvatljivim. $\ll^{38}$

Ovim se poziva da predmet mišljenja bude ono što je njega dostojno - ideja - i moguće je da Platon već ovdje daje nagovještaj nužnosti su-učešća ideja, što se često ističe kao smisao dijaloga. Na ovom mjestu zbiva se Zenonovo istupanje iz dijaloga i u prvi plan stupa Parmenid, nastojeći preispitati Sokratovu tezu o ideji. Sokrat prihvaća postojanje ideje pravednog, lijepog, dobrog, ali za ideju čovjeka, vatre i vode kaže da je u bespuću, dok za ideje kose, blata i prljavštine kaže da su onakve kakvim ih vidimo, te da bi bilo čudno postaviti ideju za svaku od njih. ${ }^{39}$ Ovim se daje nagovještaj da predmet istraživanja ne smije biti unaprijed postavljen, odnosno da teorija ideja ne smije biti shvaćena kao ona koja unaprijed postavlja ili isključuje moguće predmete istraživanja. Neophodno je izbjeći svako postuliranje i svakom predmetu istraživanja dati podjednaku šansu da se okuša. ${ }^{40}$

Parmenid ukazuje na mladost i neupućenost Sokrata u filozofiju i počinje s "napadom « na tzv. teoriju ideja. Napad na postavku ideje je prije svega napad na odnos ideja-stvar, što još jednom potvrđuje da ideja uvijek već nekako jest istina onoga promjenljivog. Sada se to nekako nastoji misliti. Ono što također treba imati u vidu jest da se napadi ne tiču jednog od načina tog odnosa, već da pogađaju svaki od njih. Oni ciljaju na nemogućnost, odnosno neodrživost

29

Parm. 127d6-128a2.

30

Platon, Parmenid, Demetra, Zagreb 2002. str. 23, 128a6-7.

31

Parm. 128b1.

32

Isto.

33

Parm. 128 b6.

34

»... očito odatle taj moj spis proturječi onima koji dokazuju ona mnoga« (Platon, Parmenid, str. 25, 128d1-2).

35

Platon, Država, BIGZ, Beograd 1993., str. 141, 454a.

36

Zvonko Posavec vidi Zenona kao antilogičara iz drugog razloga: »... može se Zenona iz Parmenida nazvati 'antilogičarem' jer se njegovo umijeće kreće u vidljivim stvarima. U Platonovu smislu dijalektika je metoda koja se kreće isključivo u području eídē. Tako Platonovo razumijevanje dijalektike osuđuje svako drugo kao 'antilogiku' [...]. Zenon je zarobljen vidljivim stvarima.« (Zvonko Posavec, Dijalektika $i$ politika, Liber, Zagreb 1979., str. 76). Ako je to tako, uzmemo li u obzir Hegelovo razlikovanje sofističke i Platonove dijalektike kao razlikovanje područja na kojem se kreću, onda se Zenon približava sofistima. Mi smo mišljenja da je »kritika« Zenona određena i smislom dijalektike kao one koja je vođena težnjom $\mathrm{k}$ zadobivanju istine, a ne kao vještina proturječja radi pobjede, što je ujedno jedan od ključnih momenata Aristotelovog razlikovanja dijalektike i sofistike. To je u Parmenidu istaknuto kao smisao Zenonove metode, što se u potpunosti podudara s Platonovom recepcijom sofistike kao vještine proturječja i podučavanja u istoj, koja nije vođena nikakvim ciljem višim od pobjede.

37

Platon, Parmenid, str. 27, 129b1-2.

38

Isto, str. 29, 129e5-131a2.

39

Parm. 130d5-10.

40

Platon u Državniku povodom tog pitanja kaže sljedeće: »... da se ovakav način raspravljanja ne brine odviše za ono što je uzvišeno nego za ono što nije, i da nimalo ne prezire ono što je neznatno zbog onog što je znatno, nego da sam po sebi ide sve do prave istine.« (Platon, Državnik, u: Platon, Kratil, Teetet, Sofist, Državnik, str. 312, 266d.) 
tako mišljenih odnosa. Napadi pokazuju da, sa svakim od predloženih načina mišljenja odnosa ideja i stvari ideje gube ono što im je svojstveno, odnosno one odlike koje su im date prije svega u Fedonu i Državi.

Pobijanje odnosa ideja-stvar, odnosno postulata ideje, sprovodi se kroz pet argumenata. Prvi napada ideje kao uzroke, tvrdeći da koncept učestvovanja, na kojem je kauzalnost ideja utemeljena, nije koherentan, svodeći ideju na nešto prostorno nalik stvarima. ${ }^{41}$ Drugi polazi od ideje kao jednog iznad mnogih, tražeći da se ideja i stvar promatraju jednako, odnosno da se odnos ideja-stvar misli u pogledu na (novu) ideju kao jedno iznad mnogih. ${ }^{42}$ Traži se ujedno da se ideja promatra nalik stvari i da je (sada nova) ideja jedno iznad mnogog kao istina odnosa (prethodne) ideje i stvari, odakle slijedi beskonačni regres. Treći napada postavku eidosa, koja se ne pojavljuje u ranijim dijalozima - da ideje nisu ništa drugo do misli, što opet završava u apsurdu. ${ }^{43}$ Četvrti napada ideje kao uzore, te za razliku od drugog argumenta, koji je naprosto tražio da se ideja i stvar promatraju na jednak način, nudi razlog zašto je to moguće - sličnost stvari ideji, gdje se sličnost razumije kao relacija bitka jednakog ontološkog statusa. ${ }^{44}$ Riječju, ideja se opet svodi na stvar uz istovremeno inzistiranje da je relacija sličnosti jedno iznad mnogog (nova ideja). I, konačno, peti napada mogućnost dostupnosti ideja saznanju, tvrdeći da postavka o ideji čini ideje nespoznatljivim (ljudima), što je najveći problem ili istinska aporija teorije ideja.

Prva četiri argumenta usmjerena su na odnos ideja-stvar. Tu kritiku izvodi Parmenid, čija misao isključuje sve ono drugo što stoji nasuprot bitka kao onog jednog sebi jednakog. Kritika je upućena Sokratovoj postavci ideje kao onog što je nalik Parmenidovom jednom-sve-biću, s tim što su one uvijek već nekako istina onog mnogog. Kritikom odnosa ideja-stvar pokazuje se da taj odnos, onako kako je mišljen, nije moguć a da pritom ideja ostane ono što jest. Ne zaključuje se da odnos kao takav nije moguć nego da ga treba misliti drugačije. To drugačije mišljenje odnosa ostaje otvorenim, makar za sada. Čini se da je osnovni problem u načinu na koji se misli biće po sebi ideja. To ističe Parmenid:

»Vidiš li, Sokrate, koliko je to bespuće ako netko kao ideje određuje bića sama po sebi. $^{45}$

Iz načina mišljenja bića po sebi ideje slijedi nemogućnost mišljenja odnosa ideje i stvari, a iz Sokratovog načina mišljenja odnosa slijedi nemogućnost bića po sebi ideje. Ako se na temelju postavke o ideji i njenog odnosa spram stvari ne da misliti taj odnos, onda slijedi potpuna odvojenost ideja i stvari. Ideje jesu to što jesu spram sebe samih i kao takve su dostupne jedino onom božanskom, a stvari koje su doduše istoimene idejama, jesu to što jesu jedne spram drugih. ${ }^{46}$

Sokratovo nastojanje da pokaže ideje kao istinu mnogih nije uspjelo i otkriva se prava teškoća tzv. teorije ideja - istinsko bespuće koje je mišljenje odnosa ideja i stvari u analogijama sve vrijeme prikrivalo. U petom argumentu se susreću Sokrat i Parmenid. Posljednjim argumentom uspostavlja se horizma onog božanskog kao čistog samo-odnosa i onoga ljudskog kao stanovišta relata po sebi, čime se zapravo potvrđuje Parmenidova misao kao ona koja uspostavlja jaz između sigurnosti lijepokruga istine bitka i dvoglavog lutanja smrtnika koje je lišeno svake istine. Puštajući Parmenida da pokaže neutemeljenost Sokratove postavke o ideji, Platon zapravo pušta Parmenida da kritizira samog sebe. Ukoliko se u Parmenidu napušta Sokrat, utoliko se napušta i Parmenid jer obojica dijele isti način mišljenja bića po sebi ideje. Doduše, napuštanje Sokrata posredstvom Parmenida nosi sa sobom nešto više, ono 
predstavlja zahtjev za utemeljenjem onoga što je Sokrat postulirao kao općost u sferi etičkog, a taj zahtjev vodi izvan sfere etičkog k Parmenidovoj misli bitka.

Već na početku dijaloga, Platon kroz Sokratov nagovor, naime da se problemi vezani za mnoštvo, kao predmet Zenonovih aporija, prikažu u području samih

41

Prvi argument je, svođenjem ideje na ontološki nivo pojedinačnog bića, naznaka smisla preostalih argumenata. Teza prvog argumenta glasi: »Čini ti se, kako kažeš, da postoje ideje, zahvaćajući u koje ona druga imaju od njih svoja imena [...]« (Platon, Parmenid, str. 31, 130e5-131a1). Parmenidov napad na ideju mišljenu kao uzrok prvo nastoji dovesti u pitanje koncept uzimanja učešća u ideji, pokazujući kako ideja ne može biti cijela (jedna), da bi potom prešao na nemogućnost odnosa ideje i stvari ako je ideja podijeljena (ako ideja kao jedna prisustvuje u mnogim bićima odvojena od sebe - bitak na način mnogih). Na tu primjedbu Sokrat ideju kao jednu $\mathrm{i}$ istu, prisutnu u mnogima, pokušava spasiti uspoređivanjem ideje s danom $(\eta \mu \varepsilon ́ \rho \alpha)$ »koji je jedan $\mathrm{i}$ isti istovremeno na mnogim mjestima« (isto, 131b2-3). Međutim, ono što iznenađuje je to da Parmenid na ovu analogiju ne odgovara direktno, nego je, a da to na prvi pogled izgleda neprimjetno, reformulira u usporedbu ideje s jedrom. Ono što začuđuje je i sama formulacija Platonove rečenice: »Baš zgodno, reče, Sokrate, jedno činiš istim istovremeno na mnogim mjestima, kao ako bi, natkrilivši jedrom mnogo ljudi [...].« (isto, str. 33, 131b7-8). Postavlja se pitanje: što je to zgodno što omogućava da analogija $\mathrm{s}$ jedrom (ono prostorno) zamijeni analogiju s danom - svjetlost ili, možda prije, vrijeme? (Usp. Kenneth Dorter, »The Theory of Forms and Parmenides I«, u: John P. Anton, Anthony Preus, Essays in Ancient Greek Philosophy III: Plato, State University of New York Press, New York 1989., str. 183-202, str. 188.) Platon je očigledno ciljao na nešto drugo kroz Sokratovu usporedbu. Naime, na to da ideje ne mogu biti mišljene kao nešto prostorno, nalik stvarima. Sokrat na takvu zamjenu teza pristaje s jednim možda! Zvonko Posavec ovo možda objašnjava Sokratovim nerazumijevanjem vlastite usporedbe, te mu iz tog razloga promiče Parmenidova zamjena teza (Z. Posavec, Dijalektika $i$ politika, str. 85). Mišljenja smo da se ovdje ne radi o nerazumijevanju (na koga god da Platon cilja kroz lik Sokrata), nego da ovo možda zapravo odvraća od svođenja ideja na ontološki nivo pojedinačnog bića. Platon je ovaj argument mogao odbiti na temelju tzv. teorije ideja razvijene još u Fedonu tvrdnjom da ideje i stvari ne mogu biti promatrane na isti način (usp. Gregory Vlastos, »Degrees of Reality in Plato«, u: Gregory Vlastos, Platonic Studies, Princeton Academic Press, Chichester 1973. str. 70). Doduše, time nije rečeno ništa o tome kako odnos ideja-stvar treba misliti, već da ono što je ranije samo postulirano sada treba uzeti kao zadatak mišljenja.

\section{2}

»A što, samo ono veliko, i ona druga velika, ako na isti način svojom dušom sagledaš, neće li se iznova pojaviti neko jedno veliko po kojemu je nužno da se sva ta pokazuju kao velika?« (Platon, Parmenid, str. 35, 132a6-8).

43

Bliskost same stvari (ideja) i spoznaje same (uma) govori da ono što jest može biti razumljivo samo ako se polazi od čistog mišljenja. To svakako ne znači da je mišljenje nešto što konstituira bitak u onom što njegovog jest, ali se to što onog što jest mišljenjem u najvećoj mogućoj mjeri otvara. Spoznaja je ono što je najbliže, ono što u najvećoj mjeri pripada onome što jest, ali Platon uvijek stavlja do znanja da je ona upravo ono najsrodnije, najsličnije, čime čuva samu stvar od svođenja na misao, odnosno naznačuje bitnu pripadnost ali i razliku mišljenja i bitka. Gadamer skreće pažnju na to da Platon nikada ne poseže za ontologijom duše kao središtem koje bi predstavljalo rješenje osnovnih problema njegove filozofije, nego da o duši i njenoj umnosti govori kao o onome što je određeno umnim poretkom univerzuma: »To se ne zbiva samo tako što on izvodi veliku analogiju duše, polisa i svijeta, što u svim područjima prvenstvo priznaje najvišoj moći duše, naime voũs koji zahvaća ono umno. Ono što se u tom poretku prvenstva i vladavine voũ $\varsigma$ ima u vidu uvijek je cjelina bitka, pa je odatle i racionalnost cjeline kretanja ono na čemu se prikazuje umnos uma. Pouzdano kruženje zviježđa, dakle kružno kretanje, a posebno sjedinjavanje stalnosti stajanja i pokrenutosti okretanja sama sebe, koje pripada kružnom kretanju, ono je što se Platonu pokazuje kao prispodoba umskog mišljenja.« (Hans-Georg Gadamer, »Platonov Parmenid i njegov kasniji utjecaj«, u: Platon, Parmenid, str. 243-264, 261). Klaus Oehler dijalektiku subjekta i objekta u antičkoj misli objašnjava na sljedeći način: »Izraz 'prevlast objektivnog' podrazumijeva da su Grci subjektivne mehanizme posredovanja, onako kako su ih oni shvatili, tretirali kao produženje mehanizma posredovanja objektivnosti Ovdje se jasno vidi da su filozofi klasične antike u pokušaju apsolutnog utemeljenja čovjekovog konačnog uma, njegovoj autonomiji negiranju njegove relativnosti, mogli vidjeti samo odstupanje od stvarnosti, a time i samootuđenje i gubitak identiteta.« (Klaus Eler 
ideja, najavljuje da je to zapravo pravi problem. ${ }^{47}$ Ideje se unutar samih sebe putem Parmenidove kritike pokazuju mnoštvenim. To ukazivanje na mnogostrukost samih ideja izvršeno je, doduše, na način da su se same ideje svodile na stvari. Promišljanje ideja na način stvari Platon je mogao odbaciti i na temelju teorije ideja postavljene u Fedonu i Državi, ali on to ne čini. Ako postoji neki pozitivan ishod svođenja ideja na stvari, onda je to taj da su ideje unutar samih sebe »mnoštvene«, da svaka ideja poziva mnoštvo drugih u igru, da u razmatranju jedne ideje kao onoga po sebi stupamo u igru ogledanja ideja. Ideje se pokazuju u onom što jesu tek kroz su-učešće ideja. Stoga Platon i upozorava na opasnost preranog skoka u načelo:

»Prerano se naime Sokrate, prije nego si izvježban, laćaš omeđivati i lijepo kao nešto, i pravedno, i dobro, i svaku pojedinu od ideja. $^{48}$

Dakle, ovdje nije u pitanju Platonovo odbacivanje bića po sebi ideje, već je u pitanju drugačiji način mišljenja njenog bića po sebi. Bez pretpostavke o biću po sebi nije moguć govor, bio on filozofski ili ne, ali i elejski način mišljenja bića po sebi, koji stoji u osnovu Sokratovog postuliranja ideje, jednako poriče mogućnost govora (što Platon pokazuje prvim prohodom kroz prvu pretpostavku »jedno jest« u drugom dijelu dijaloga). Biće po sebi ideje sada postaje predmet istraživanja ili ono nije naprosto postulirano, nego se o njegovoj posebnosti i dostojnosti mora položiti račun. Ako su ideje Parmenidovom kritikom pokazane kao »mnoštvene«, ako se »svijet« ideja pokazuje u međusobnom preplitanju ideja, onda se ideje pokazuju na način koji je analogan Parmenidovom putu mnijenja smrtnika - putu onih koji lutaju dvoglavi. To znači da nema puta sigurnosti samoodnošenja bića po sebi, što vodi opasnoj blizini filozofa (Parmenida) i sofiste. Međutim, susret onih najudaljenijih pokazuje se kao susret onih najbližih, a pristajanje na opasnost te blizine je za Platona pristajanje na mogućnost onoga spasonosnog, puta između. Taj put je dijalektika, ona koju »mnoštvo naziva brbljanjem $«,{ }^{49}$ kao trag božanskog, ${ }^{50}$ put(okaz), »zapleteno i tumarajuće ispitivanje «. ${ }^{51}$

Ono što karakterizira Platonovu situaciju jest to da bitak više ne govori svojom potpunom neskrivenošću kako je to slučaj, čini se, kod Parmenida. Božansko se ne obraća direktno, ne otvara se neposredno cjelina bitka u svojoj prisutnosti. Jedino što je ostalo kao trag božanskog je dijalektika. Ako je to tako, onda se bludnja i besputnost pokazuju kao jedini preostali put. Taj put može se razumjeti kao treći put unutar Parmenidove poeme, put za koji boginja kaže da je »nužno ispitati brižljivo posve kroz sve u svemu«. Platon u Parmenidu određuje vlastiti program riječima koje zvuče kao svojevrsna invertirana parafraza Parmenidovog puta mnijenja:

»Jer mnoštvo ne zna da je bez tog potpunog prolaženja i lutanja kroz sve nemoguće, namjerivši se na ono istinito, doći do uma.«52

Iz same se Poeme ne vidi zašto je nužno ispitati put onih koji lutaju dvoglavi, ali za Platona se taj put pokazuje kao jedini mogući put istraživanja.

\section{III.}

Prolaženje kroz igru ogledanja ideja pokazuje se kao mogućnost zadobivanja onoga posljednjeg, ali ono ujedno predstavlja opasnost. Jedno je sigurno: ukoliko se želi steći konačni uvid, utoliko se mora besputiti. U Parmenidovoj poemi boginja na više mjesta zabranjuje mladiću da ide drugim putovima, da besputi. Ona se pojavljuje kao zakonodavstvo bitka i zabranjuje svaki drugi 
put koji nije u skladu s putem »da jest«. Imajući to u vidu, Platon u Sofistu kaže da se mora učiniti nasilje, ako se želi steći uvid u cjelinu, mora se prekršiti zakon. ${ }^{53}$ Ovaj moment predstavlja Platonovo obznanjivanje napuštanja Parmenida. Platon se odlučuje na zabranjeni put. Ali i više od toga, taj put je za njega jedina mogućnost uvida u cjelinu jer

»... nužno je naime upoznati u isto vreme oboje, i laž i istinu u pravom biću [...]. ${ }^{54}$

Drugi, »gimnastički« dio dijaloga Parmenid jedno je od najtežih mjesta za interpretaciju unutar Platonovih djela. Koji je smisao dijalektičke igre koja putem osam (ili devet) prolaza kroz dvije pretpostavke naizgled završava u potpunom apsurdu? Interpretacije drugog dijela dijaloga su najrazličitije i idu od potpunog poricanja bilo kakvog pozitivnog smisla drugog dijela za probleme postavljene u prvom dijelu dijaloga, gdje se prvi dio razumije kao puka vježba lišena sućinskih uvida (dijalektička vježba bliska Aristotelovom razumijevanju dijalektike), do nečega što je od odlučujućeg značaja za probleme postavljene u prvom dijelu, odnosno za utemeljenje ideja. Mi se ovdje ne možemo poduhvatiti iscrpne interpretacije drugog dijela dijaloga, nego ćemo istom pristupiti kao naznaci Platonovog poznog mišljenja bitka te ukazati na ulogu elejaca unutar programa dijalektičke igre koja se najavljuje kao moguće rješenje aporija u koje se zapalo u prvom dijelu dijaloga.

Platon u »gimnastičkom « dijelu dijaloga pokazuje nužnost mišljenja su-učesništva ideja, pokazuje ono što će pokušati izložiti i utemeljiti kroz učenje o najvišim rodovima u Sofistu. Platon u Sofistu otvoreno ustaje protiv oca Parmenida, ali u samom Parmenidu logika kritike elejskog učenja već je po-

[Klaus Oehler], Subjektivnost $i$ samosvest $u$ antici, Plato, Beograd 2002., str. 43).

44

U komentaru ovog djela, Petar Šegedin ukazuje na problematičnost ovako razumljene relacije sličnosti: »... pod nalikom razumijem biće kojega sa svojim uzorom povezuje sličnost po kojoj mu nalikuje, ali je ustvari ipak nešto od njega drugo te mu može, u većoj ili manjoj mjeri, samo i tek nalikovati. U tom smislu bi naliku trebalo misliti u bitnoj svezi

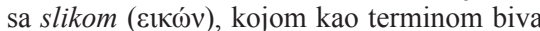
naglašen više sam čin odslikavanja nego sveza sličnosti i nalikovanja koja povezuje uzor $\mathrm{i}$ ono $\mathrm{u}$ čemu se on odslikava.« (Platon, Parmenid, str. 149)

45

Isto, str. 39, 133a8-9.

46

Čini se da Platon kroz Sokratov lik već u $F e$ donu upućuje na mogućnost ove aporije, kada u posljednjem dokazu za besmrtnost duše govori o ideji veličine.

47

»Ta pretpostavka o idejama nije sama o sebi već Platonova filozofija, nego tek postavljanje filozofske zadaće. Kao što se pokazuje u Parmenidu, pojedinu ideju »za sebe« uopće nije moguće spoznati. U tome je pogreška koju čini mladi Sokrat. U svakoj je spoznaji u igri cijeli sklop i splet ideja, i Platon pita za one temelje koji izgrađuju i organiziraju ova strukturni sklop ideja.« (Hans-Georg Gadamer, »Dijalektika i sofistika u Platonovu Sedmom pismu«, u: Platon, Državnik, Sedmo pi smo, Liber, Zagreb 1977., str. 153-179, 176) 48 Platon, Parmenid, str. 45, 135c8-d1. 49

Isto, str. $47,135 \mathrm{~d} 5$.

50

»Kao božanski dar ljudima, kako se bar meni čini, bačen je taj put od strane bogova preko nekog Prometeja zajedno s nekom veoma sjajnom vatrom.« (Platon, Fileb, u: Platon, Dijalozi Teetet i Fileb, str. 120, 16c)

51

Platon, Parmenid, str. 47, 135e2-3.

52

Isto, str. 49, 136e1-3.

53

»Bit će nužno da zbog naše obrane podvrgnemo ispitivanju tezu oca Parmenida i da na silu utvrdimo da nebiće u izvjesnom smislu postoji i opet sa druge strane da biće na neki način ne postoji.« (Platon, Sofist, str. 245, 241d)

54

Platon, Sedmo pismo, u: Platon, Državnik, Sedmo pismo, str. 129, 344b. 
stavljena, kao što je u istom dijalogu postavljena i logika kritike sofista (posebno Protagore u Teetetu). Problem koji je postavljen u prvom dijelu dijaloga problem je odnosa ideja-stvar, gdje se pokazalo da ni jedan način mišljenja tog odnosa nije zadovoljavajući. Međutim, iz toga nije izveden zaključak da odnos nije moguć, nego da ga treba misliti drugačije. Treba ga utemeljiti u nečem drugom, o čemu se ništa otvoreno nije reklo. Zaključak je izgledao paradoksalno: ako se postavi bitak po sebi ideje onda nema saznanja tog bitka, a ako se bitak po sebi ideje ne postavi, uopće nema saznanja - »A što ćeš onda činiti glede filozofije? Kamo ćeš se okrenuti ako one ne znaju? «55 Parmenid ne predstavlja samo (»prikrivenu«) raspravu s elejcima, gdje Platon posredstvom Parmenida nastoji da ono što je istom dugovao (način mišljenja posebnosti ideja) kritički i ne bez ironije vrati, već i kritiku sofistike koju Platon razumije kao odsustvo onoga posebnog, odnosno jednog.

Pravi problem i mogućnost rješenja istog je već na samom početku dijaloga naznačen onim što bi za mladog Sokrata predstavljalo predmet najvećeg divljenja: da ideje su-učestvuju, da se prepliću. ${ }^{56} \mathrm{U}$ tom pogledu upućuje se na dijalektiku kao put $\mathrm{k}$ rješenju i zaključuje neiskustvo u dijalektici mladog Sokrata i potreba za vježbom u istoj. Metoda, odnosno način vježbanja koji se predlaže je »upravo taj [...] kojeg si čuo od Zenona«, s tom razlikom što se on sada kreće na području ideja. Ali i više od toga:

»... ne razmatrati samo što, ako postoji svako pojedino postavljeno (biće), slijedi iz te pretpostavke već i pretpostaviti da to isto nije, ako želiš biti bolje izvježban. «57

Ispitivanje treba položiti u osnovu da isto jest, a i nije, pa vidjeti što slijedi kako za to samo po sebi, tako i u odnosu na drugo, a i za drugo kako po sebi, tako i u odnosu na drugo. ${ }^{58}$ Time se pokazuje nužnost prolaženja i lutanja kroz svako nemoguće da bi se došlo do istine.

Osnovni pojmovi koji se ovdje predlažu kao mogući predmeti istraživanja su: jedno, mnogo, sličnost, nesličnost, kretanje, stajanje, postajanje, nestajanje, biti, nebiti. Međutim, ono što se u samom dijalogu jedino stavlja u osnovu ispitivanja jest jedno za koje Platonov Parmenid kaže da je njegova pretpostavka. ${ }^{59}$ Ovim se postavljaju dva pitanja. Prvo, je li opravdano to što Platon Parmenidovu misao bitka sažima u stav »Sve je Jedno«. U samoj poemi se određenje bitka kao jednog javlja samo jedanput (DK B8 6), tako da može izgledati kao da Platon iznova tumači Parmenidovu misao bitka ili da je razumije shodno Zenonu koji naglasak stavlja na problem jednog (bića) i mnoštva (bića). Međutim, ono što Zenon potencira svojim aporijama proizlazi upravo iz osnova Parmenidove misli bitka, tako da je nemoguće tvrditi sućinsko poravnanje između ova dva mislioca. Stav »Sve je Jedno« mora se uzeti u cjelini. Naime, nije u pitanju to da Platon razumije Parmenida isključivo henološki, nego da ga razumije kao onoga koji misli bitak kao jedno i jedino, jedno i sve.

Drugo, zašto Platon kao pretpostavku ne uzima samo mnoštvo (a i od navedenih pojmova), ako je njegova misao - misao jednog i mnoštva, a mnoga su i predložena kao mogući predmet istraživanja? Strogo uzevši, ne prolazi se kroz mnoga kao pretpostavku istraživanja. Međutim, to da je svaki od prolaza prohod kroz jedno ne govori o tome da se zapravo razmatra jedno samo (to može važiti samo za prvi prohod prve pretpostavke). Naprotiv, u pitanju je nužnost su-mišljenja jednog i mnogih, a tu nužnost pokazuje svaki od prohoda kroz dvije pretpostavke s različitih strana. U Sofistu se Parmenidov bitak pokazuje diferenciranim, unutar sebe različitim, a nebitak kao ono drugo bitka. U Parmenidu se pokazuje neprestano prožimanje jednog i mnogih na svim 
razinama. Dakle, da se ne govori o mnogima, samo je privid. Tu se ne govori ni samo o jednom ni samo o mnogima, već je riječ o tome da ukoliko se hoće govoriti o jednom, utoliko se mora govoriti o mnogim, a ukoliko se hoće govoriti o mnogim, utoliko se mora govoriti o jednom. U drugom dijelu dijaloga, kao i u kasnijem dijalogu Sofist, dolazi do susreta filozofa (Parmenida) i sofiste, »prijatelja ideja « $\mathrm{i}$ »materijalista«, sada, čini se, kao susreta jednog $\mathrm{i}$ mnogih, a ne susreta bitka i nebitka. ${ }^{60}$ Međutim, ono što se pokazuje u Parmenidu upravo je mnogostrukost izricanja najviših pojmova, kao i u Sofistu, zato što svaki prolaz kroz pretpostavku »jedno jest « i »jedno nije« pretpostavlja različito tumačenje onog jest $\mathrm{i}$ onog nije o kojima zavisi dalje izvođenje. ${ }^{61}$

Kao što je već rečeno, u drugom dijelu dijaloga se nastoje posredovati ekstremi koji su jednako kobni, i koji padaju u jedno. Čak i sama struktura drugoga dijela dijaloga pokazuje da, iako oni na prvi pogled izgledaju najudaljeniji, oni su toliko bliski da mišljeni konzekventno tvrde isto - poriču mogućnost $\operatorname{logosa}{ }^{62}$ Tako prvi prolaz prve pretpostavke »jedno jest« uzima jedno kao jedno samo - jedno u horizontu samosti, što upravo predstavlja Parmenidovu misao bitka, koja je ovdje izvedena do svojih krajnjih konzekvenci. ${ }^{63} \mathrm{~S}$ druge strane, posljednji prohod kroz drugu pretpostavku »jedno nije« uzima mnogo kao ono samo, što predstavlja sofistiku, onako kako je Platon razumije. Posljedica prve pretpostavke je da jedno koje je mišljeno kao osamljeno jedno nije nijedno, odnosno da nema ničega ako se jedno tako postavi. Ukoliko će biti jednog, utoliko mora biti mnogog, to daljnje ispitivanje prve pretpostavke i potvrđuje. Druga krajnost ima za posljedicu da ukoliko se mnoga postave, utoliko naprosto kao mnoga onda ona nisu ni mnoga; riječju nema ničega ukoliko se mnoga tako postave. Ukoliko će biti mnogih, utoliko mora biti jednog. Te dvije krajnosti Platon pokazuje kao one koje nužno upućuju jedna na drugu i u tom upućivanju, same sebe ukidajući, traže posredovanje. Platon pokazuje nužnost jednog za mnoga i mnogih za jedno, ali i više od toga, on pita za mogućnost mišljenja te nužnosti, što će biti zadatak projekta označenog kao patricid u Sofistu.

55

Platon, Parmenid, str. 45, 135c5-6.

56

Platon kroz Sokrata u Filebu govori o potrebi određenja onog što je izvan uobičajenih rasprava, o potrebi za onim »što još nije odobreno ni općenito prihvaćeno« (Platon, Fileb, str. 118, 14e) te o nužnosti razmatranja onoga »što bi se činilo najnemogućijim od svega, naime da jedno nastaje ujedno u jednome i u mnoštvu. To je [...] pitanje o jednome i o mnoštvu, koje je uzrok svake sumnje ako nije točno riješeno i opet uzrokom sigurnosti ako je riješeno valjano.«(Isto, 15b-c).

57

Platon, Parmenid, str. 47, 135e7-136a2.

58

Parm. 136b7-c5.

59

Parm. 137a7-b4.

60

Usp. John A. Palmer, Plato's Reception of Parmenides, Clarendon Press, Oxford 1999. str. 148-181.
61

Usp. Gwilym E. L. Owen, »Plato on Not-Being «, u: G. E. L. Owen, M. C. Nussbaum (ur.), Logic, Science, and Dialectic, str. 104-137, str. 118 .

62

Usp. Hans Krämer, Platonovo utemeljenje metafizike. Studija o Platonovu nepisanom učenju i teorija počela, Demetra, Zagreb 1997., str. 166-169.

63

Usp. F. M. Cornford, Plato and Parmenides, str. 134. Govor o jednom mišljenom elejski kao osamljeno jedno može imati jedino formu »niti-niti«. Zaključak koji Platon izvodi u prvom prohodu kroz pretpostavku »jedno jest « je sljedeći: »Tada ono nikako nije. - Ne, čini se. - A nije onda tako da je jedno; jer bi (tako) već bilo i u jestvu sudjelovalo [...]. A ono što nije, može li išta postojati za taj nebitak ili (biti), njegovo? - Kako bi? - Nema dakle za njega niti imena, niti odredbe, niti kakva znanja, niti opažanja, niti mnijenja.« (Platon, Parmenid, str. 63, 141e10-142a5). 


\title{
Zaključak
}

Platonova pozna misao svjedoči o pokušaju suočavanja s vlastitim pretpostavkama. Dano suočavanje pokazuje da u osnovi misli o ideji stoji Parmenidov način mišljenja bitka. Kako su ideje kao ono jedno, vječno i nepropadljivo uvijek već istina pojedinačnih stvari, kao onog mnoštvenog, promjenljivog i propadljivog, tako se Platonova pozna misao nastoji izboriti za nov način mišljenja ideja kao bića po sebi, koji bi napustio Parmenidov način mišljenja bitka. Ukoliko se želi utemeljiti misao ideje kao one koja je uvijek već istina mnoštva, utoliko se napuštanje Parmenidovog načina mišljenja bitka, koje se pokazuje kao skrivena pretpostavka Platonove misli ideje u zrelim dijalozima, ispostavlja nužnim. Parmenidova misao bitka izlaže ga kao solitarnog, kao jedno-sve-biće, kao onog koji isključuje svaku razliku i svako mnoštvo, dok Platonova misao nastoji misliti stvarnost kao jedinstvo, gdje se ono jedno pokazuje kao istina mnoštva.

Kako je Platon jedna od centralnih figura u povijesti filozofije, čija misao bitno određuje njen daljnji tijek, tako je i njegova recepcija Parmenidovog mišljenja jedno od ključnih i nezaobilaznih mjesta u njegovom razumijevanju. Kritičko suočavanje s vlastitim pretpostavkama, koje odlikuje poznu Platonovu misao, ukazuje na fundamentalni značaj Parmenidovog mišljenja bitka za Platonovu ontologiju. Platon pokazuje koliko svaka misao duguje Parmenidu, ali i ukazuje na nužnost kritičkog suočavanja s njim.

\section{Nikola Tatalović}

\section{Plato and Parmenides: Blunder and Impassable}

\begin{abstract}
This paper analyses the relationship between Plato's late thought of being and eleatic heritage that is at the very core of Plato's middle period idea thesis. The analysis shows that Parmenides' poem On Nature represents the framework for problems regarding Plato's thought. That is, that the establishing of the concept of idea, which is simply postulated in the middle period, must be realized through criticism of Parmenides' thought of being. In a way, Plato's ideas are multiplied Parmenides' being, but as such they are always the truth of many. Therefore, establishing the concept of idea requires a critique of Parmenides' thought of being, a critique that opens a horizon for a new way of thinking ideas in terms of being as being. Patricide is Plato's decision for the impassable, a blunder that leads to the way of those who wander two-headed.
\end{abstract}

Key words

Plato, Parmenides, idea, being, non-being, one, many, truth, opinion, impassable 